\title{
Identification of alleles for sweet phenotype in local corn varieties in southern Brazil
}

\author{
Identificação de alelos para o fenótipo doce em variedades locais de millho no Sul do Brasil \\ Identificación de alelos para el fenotipo dulce en variedades locales de maíz en el sur de Brasil
}

Received: 03/26/2021 | Reviewed: 03/03/2021 | Accept: 04/08/2021 | Published: 04/18/2021

\author{
Rosenilda de Souza \\ ORCID: https://orcid.org/0000-0001-7820-2516 \\ Federal University of Santa Catarina, Brazil \\ E-mail: rosenilda.agro@hotmail.com \\ Juliana Bernardi Ogliari \\ ORCID: https://orcid.org/0000-0003-2644-3179 \\ Federal University of Santa Catarina, Brazil \\ E-mail: juliana.bernardi@ufsc.br \\ Rose Mari Seledes \\ ORCID: https://orcid.org/0000-0002-8893-7281 \\ Federal University of Santa Catarina, Brazil \\ E-mail: rosemariseledes@gmail.com \\ Wagner Bastos dos Santos Oliveira \\ ORCID: https://orcid.org/0000-0002-5384-9636 \\ Federal University of Santa Catarina, Brazil \\ E-mail: wobastos@yahoo.com.br \\ Tassiane Terezinha Pinto \\ ORCID: https://orcid.org/0000-0001-6575-7635 \\ Federal University of Santa Catarina, Brazil \\ E-mail: tassi.tp@gmail.com
}

\begin{abstract}
Sweet corn (Zea mays L.) has high levels of sugar in the endosperm, being used for self-consumption by families in the far west of the state of Santa Catarina (FWSC), southern Brazil. The present work aimed to identify the genes responsible for the sweet phenotype and to characterize morphologically nine local corn varieties conserved in this region. The allelic tests proved the presence of two known recessive alleles (sugaryl mutant/sweet and shrunken 2 mutant/super sweet) in eight of the nine varieties studied, and a third gene of unidentified genetic origin. The morphological characterization of ear and grain showed a similarity between the varieties for qualitative characters and a greater variation between and within the varieties for quantitative characters. The cluster analysis divided the materials into four groups and one isolated variety whose gene encoding the sweet phenotype can be a rare gene or still unknown. The results point to the possibility of a new allele having been selected under the specific conditions of the FWSC region, which presents environmental and social factors that influence the diversification of the Zea genus. The continuation of genetic studies on the sweet phenotype of this variety and the development of integrated strategies of in situ on farm and ex situ conservation and participatory breeding in FWSC can contribute to the expansion of the genetic variability of sweet corn and encourage conservation and use of this local germplasm.
\end{abstract}

Keywords: Zea mays; On farm conservation; Germplasm characterization; Sugary1; Shrunken2; Xenia phenomenon.

\section{Resumo}

O milho doce (Zea mays L.) apresenta elevados terores de açúcar no endosperma, sendo utilizado para autoconsumo por famílias da região do extremo oeste de Santa Catarina (EOSC), Sul do Brasil. O presente trabalho objetivou identificar os genes responsáveis pelo fenótipo doce e caracterizar morfologicamente nove variedades locais de milho conservadas nessa região. Os testes alélicos comprovaram a presença de dois alelos recessivos conhecidos (mutante sugaryl/ doce e mutante shrunken2/ super doce), em oito das nove variedades estudadas, e um terceiro gene de origem genética não identificada. A caracterização morfológica de espiga e grão apontou similaridade entre as variedades para caracteres qualitativos e uma maior variação entre e dentro das variedades para caracteres quantitativos. A análise de agrupamento dividiu os materiais em cinco grupos e uma variedade isolada, cujo gene que codifica o fenótipo doce pode ser um gene raro ou ainda desconhecido. Os resultados apontam para a possibilidade de um novo alelo ter sido selecionado, nas condições específicas da região do EOSC, cujos fatores ambientais e sociais têm influenciado na diversificação do gênero Zea. A contribuição de estudos genéticos sobre o fenótipo doce desta variedade e o desenvolvimento de estratégias integradas de conservação in situ on farm e ex situ e melhoramento genético participativo no EOSC podem contribuir para a expansão da variabilidade genética do milho doce e estimular a conservação e uso deste germoplasma local.

Palavras-chave: Zea mays; Conservação on farm; Caracterização de germoplasma, Sugaryl; Shrunken2; Fenômeno xênia. 


\section{Resumen}

El maíz dulce (Zea mays L.) posee altos niveles de azúcar en el endospermo, es utilizado para autoconsumo por familias de la región del extremo oeste de Santa Catarina (EOSC), sur de Brasil. El objetivo del presente trabajo fue identificar los genes responsables del fenotipo dulce y caracterizar morfológicamente nueve variedades locales de maíz conservadas en esta región. Las pruebas de alelos mostraron la presencia de dos alelos recesivos conocidos (sugary1/ mutante dulce y shrunken2/ mutante superdulce) en ocho de las nueve variedades estudiadas y un tercer gen de origen genético no identificado. La caracterización morfológica de mazorca y grano mostró similitud entre las variedades para caracteres cualitativos y una mayor variación entre y dentro de las variedades para caracteres cuantitativos. El análisis de conglomerados dividió los materiales en cinco grupos y una variedad aislada cuyo gen que codifica el fenotipo dulce puede ser un gen raro o desconocido. Los resultados apuntan a la posibilidad de que se haya seleccionado un nuevo alelo bajo las condiciones específicas de la región del EOSC, que presenta factores ambientales y sociales que influyen en la diversificación del género Zea. La contribución de estudios genéticos sobre el fenotipo dulce de esta variedad, el desarrollo de estrategias integradas de conservación in situ on farm y ex situ y el mejoramiento genético participativo en el EOSC pueden contribuir a la expansión de la variabilidad genética del maíz dulce y fomentar la conservación y uso de este germoplasma local.

Palabras clave: Zea mays; Conservación on farm; Caracterización de germoplasma; Sugaryl; Shrunken2; Fenómeno xenia.

\section{Introduction}

Sweet corn (Zea mays L.) is a special type of maize used for human consumption in fresh or industrialized form. It differs from other types of maize for having one or more genes that alter the starch synthesis in the endosperm, with consequent changes of texture, flavor, aroma, and softness of the grains (Tracy, 2001). The genes encoding the sweet phenotype can be divided into two classes, based on their effects on the composition of the endosperm. Class I mutants brittle1 (bt1); brittle2 (bt2); shrunken2 (sh2) - accumulate sugar at the expense of starch and have genotypes with high sugar content, and therefore they are called super sweet or extra sweet. Class II mutants - amylose extenserl (ae1), dull1 (dul), sugaryl (sul), waxyl (wxl) - have altered the types and amounts of polysaccharides produced, but in lesser quantities than those of class I, and therefore they are called sweet (Boyer \& Shannon, 1984). The combination of class II mutant genes results in sugar levels equal to those found in class I mutants (Boyer \& Shannon, 1984).

Although many mutants confer the sweet phenotype, the genetic diversity of this type of maize is small, with only 300 open-pollination varieties described in the world, many of which are derived from sweet corn breeding programs (Tracy, 2001). In Brazil, of the 4,000 accessions of corn conserved by the principal genebank of the country - Brazilian Agricultural Research Corporation (Embrapa) -, only 20 are characterized as sweet corn (Teixeira et al., 2019) and none come from collections made in the Santa Catarina state, in the south region of Brazil. Despite initiatives to rescue genetic material from maize, in the various Brazilian biomes, there are still many regions in Brazil that harbor an expressive and unknown diversity of local varieties with rare use values and adaptive values to particular agricultural ecosystems (Coradin, 2006).

Among the regions of Brazil recognized by the high diversity of local varieties and wild populations of the Zea genus, the far west of Santa Catarina (FWSC) state stands out (Ogliari \& Alves, 2007; Costa, Silva \& Ogliari, 2016; Reichert Jr. et al., 2020; Silva, Vidal \& Ogliari, 2017). Located in the Atlantic Forest Biome and within the Rio das Antas Valley, this region is indicated as a microcenter of maize diversity (Costa et al., 2016). The constant adaptive and evolutionary processes (Silva et al., 2017) and the coevolution in the presence of wild populations of the species (Silva, Vidal, Costa, Vaio \& Ogliari, 2015) led to the diversification of corn in this region, such as the formation of new races of popcorn identified by Silva et al. (2017). Incentive measures for the conservation in situ on farm, sustainable use of agricultural biodiversity, and participatory breeding should be a priority in this region (Costa et al., 2016; Ogliari \& Alves, 2007; Silva, Vidal, Ogliari, Costich \& Chen, 2020; Souza, Ogliari \& Pinto, 2020). Focused on local communities, the participatory breeding combines farmers' knowledge, skills, experiences, practices, and preferences with the knowledge of researchers, makes use of a local genetic base and boosting its conservation and use (Almekinders \& Elings, 2001; Machado, 2014; Ogliari, Kist \& Canci, 2013). 
In this region (FWSC) rich in agricultural diversity, 31 were sweet corn and common maize with sweet taste (Souza et al., 2020), of a total of 1,513 local populations of maize identified by Costa et al. (2016). The identification of the mutant allele responsible for the sweetness of the grain in sweet corn varieties can be made from an allelic test, crossing maize varieties of unknown sweet genotype with materials of known genotype (Coe, 1985; Strickberger, 1968). The allelic crossing method or genetic complementation is efficient in field studies to validate the allelic relationships between sweet corn mutants, since the changes in the chemical composition, size, shape, color and development time of the grains, as a function of genetic nature of the pollen responsible for fertilization, are visible in the F1 generation (Jha, Singh \& Agrawal, 2016). Such effect, which alters the chemical and morphological characteristics of the grain, is known as the xenia phenomenon (Denney, 1992) and results from a direct effect of pollen on the embryo and endosperm, after fertilization and development of the grain.

Considering the limited diversity conserved in the national genebanks and the scarce information about these genetic resources, conserved both in situ and ex situ, the present study aimed to identify the genes responsible for the sweet phenotype and to characterize morphologically, for ear and grain characters, nine local varieties of sweet corn conserved in the FWSC region.

\section{Methodology}

\subsection{Plant material}

Nine local varieties of sweet corn were collected in family production units in the municipalities of Anchieta and Guaraciaba, located in southern Brazil, western mesoregion of Santa Catarina state and in the extreme west microregion. This region is characterized by small-scale farmers and diversified production of crops and animals.

As a test material, three sweet corn cultivars (BR 400, BR 401 and BRS Vivi) developed by the Embrapa' breeding program and one sweet corn access (Doce Cubano) from the Embrapa's Maize Active Genebank (Maize BAG) were used. The BR400 super sweet cultivars, carrying the bt2bt2 genotype, and BR401 sweet, carrying the sulsul genotype, were launched by the Embrapa in 1980s and developed from genetic material introduced from Hawaii (Cardoso, Sereno \& Barbosa Neto, 2002; Reifschneider, Gama \& Reis, 1984); the super sweet hybrid BRS Vivi, carrying the sh2sh2 genotype, was formed by exotic inbred lines containing the recessive allele shrunken2 (sh2) and dent and semi-dent maize lines (Teixeira et al., 2014), and launched by Embrapa in 2010; the access Doce Cubano, carrier of the sulsul genotype, was introduced in Brazil in 1979. The choice of sugaryl (sul), shrunken2 (sh2) and brittle2 (bt2) genes to perform allelic tests was due to the following factors: commercial importance of the mutants, the most produced in Brazil; representativeness of the two classes of mutants (class I super sweet and class II - sweet); and genetic relevance of the sugaryl mutant, as it is one of the first genetically characterized, the oldest introduced in Brazil and responsible for the sweet phenotype of most maize accessions of Embrapa's Maize BAG (Teixeira et al., 2019).

\subsection{Allelic tests}

The allelic tests for the identification of the genes responsible for the sweet phenotype were carried out in four areas individually for each of the four testers (BR 400, BR 401, BRS Vivi and Doce Cubano) at Fazenda Experimental da Ressacada/ Universidade Federal de Santa Catarina (UFSC), in Florianópolis, in the 2016/2017 season. Each of these areas consisted of 12 rows of five linear meters in length, spaced $1.0 \mathrm{~m}$ apart, at a density of 50,000 plants ha ${ }^{-1}$, with spatial and temporal isolation. For the identification of the mutant allele in local varieties, a known genotype material was used as a pollen donor (pollinator), while the nine local varieties of the FWSC were egg donors. Pollination was carried out manually and each pollinated ear received an identification number. A total of 500 crosses were evaluated visually for the type of grain based on the resulting phenotype. Considering the recessive character, the varieties that kept the wrinkled grain of the sweet type, after 
crossing, were considered to have the same recessive homozygous genotype as their tester. On the other hand, varieties that lost the characteristic of wrinkled grain after crossing were considered to have a different genotype from their tester.

\subsection{Phenotypic characterization}

The phenotypic characterization was carried out from a sample of the varieties donated by the maintainers (farmers), based on morphological characters evaluated in five ears and ten grains per ear of each variety, according to the minimum descriptors of the culture (IBPGR, 1991; MAPA, 1997), namely: color of the grain (GC), color of the grain pericarp (PC), color of the endosperm (ENC), shape of the grain (GS), shape of the ear (ES), number of rows (NR), arrangement of the rows (RA), cob color (CC), number of grains per row (NGR), ear length (EL), ear diameter (ED), grain length (GL), grain width $(\mathrm{GW})$ and grain thickness (GT).

The ear and grain characterization data were submitted to descriptive with the aid of the PAST 3.04 software. For nominal variables, the mode was used for classification within each data set. For the quantitative variables, the average of the data was considered and the confidence interval at $95 \%$ reliability was estimated by the Student's t-distribution. Nine variables were used for the cluster analysis, excluding those with less variation and correlated. The existence of correlation was verified using Pearson's correlation coefficient. To generate the dendrogram, a distance matrix was created using the Gower method. To construct the clusters, the Unweighted Pair-Group Method using Arithmetic Averages (UPGMA) method was used, based upon the PAST 3.04 program (Hammer, Harper \& Ryan, 2001). The cutoff point was established based on the average between the lowest and highest value of the distance matrix (Mingoti, 2005), with an adjustment by the researchers. The principal component analysis method (PCA) was used to identify the characters responsible for the variation between varieties. The analysis of PCA was performed using the software Package R (Chambers, 2008).

\section{Results and Discussion}

The allelic tests showed the presence of known recessive alleles for the sweet character in eight of the nine local varieties studied (Table 1), with the sugaryl mutant of class II (sweet) being identified in seven varieties, and the shrunken 2 mutant of class I (super sweet) in one variety.

The confirmation of the presence of the recessive alleles was possible from the change in the chemical composition of the grains, in the generation of the mother plant, due to the nature of the pollen to be distinct from the fertilized maternal gamete, called the xenia effect in maize (Denney, 1992). In sweet corn, the changes due to this effect are in the magnitude of the composition of the endosperm (Kiesselbach, 1926), which result in the wrinkled appearance of the grain after drying. The composition is affected by the change from a sweet endosperm to a starch-rich endosperm, after fertilization of the egg by a non-sweet or sweet corn pollen grain, but with a distinct genotype for this character.

The local varieties 2029A, 741B, 2514A, 2276A, 319A, 3000A, and 2255A presented grains of the sweet type (wrinkled and translucent) when crossed with the varieties BR 401 and Doce Cubano (Figure 1a, b), carrying the homozygous recessive genotype sulsul (sugaryl mutant allele). The same varieties showed dent, semi-flint or flint grains when crossed with the BRS Vivi genotype, carrying the $s h 2 s h 2$ genotype, and BR400, carrying the bt2bt2 genotype (Table 1). The 2276A variety, for example, presented semi-flint and dent grains when crossed with the BRS Vivi hybrid (Figure 1c).

The crossing of the variety 3001A (orange and wrinkled grain) with the BRS Vivi hybrid (sh2sh2 genotype of yellow and wrinkled grains) resulted in sweet grains, even when reciprocal crosses were performed (Figure 1d, e). This result proves the presence of the shrunken 2 mutant allele, class I super sweet, as responsible for the sweet phenotype in the local variety 3001A (Table 1). When the variety 3001A (orange-yellow grain) received pollen from the super sweet variety BR400 (orangeyellow grain, genotype $b t 2 b t 2$ ), the result was yellow-orange of the flint grains (Figure 1f). Both varieties showed the super 
sweet phenotype, but with different mutants in recessive homozygosis. The crossing of the 3001A with the accessions Doce Cubano and BR401, carrying the sugaryl gene, presented semi-flint and flint grains, respectively.

The $2433 \mathrm{~F}$ variety did not present sweet grains when crossed with the accessions of known genotype and, therefore, it was not possible to identify the mutant allele responsible by phenotype sweet, which may be a rare mutant allele or an unidentified allele yet.

Table 1. Color and type of grain resulting from allelic crosses between local maize varieties from the far west of the state of Santa Catarina (FWSC) and varieties of known genotype for the sweet phenotype.

\begin{tabular}{|c|c|c|c|c|}
\hline \multirow{4}{*}{$\begin{array}{l}\text { Local } \\
\text { Varieties a } \\
q\end{array}$} & \multicolumn{4}{|c|}{ Known Genotype Materials ${ }_{0}^{\Uparrow}$} \\
\hline & BR 400 - Super Sweet & BR 401 - Sweet Gold & Doce Cubano & BRS Vivi \\
\hline & $(b t 2 b t 2)$ Class I $^{\mathrm{b}}$ & (sulsul) Class II ${ }^{\mathrm{b}}$ & $\left(\right.$ sulsul) Class II ${ }^{\mathrm{b}}$ & $(\operatorname{sh} 2 \operatorname{sh} 2)$ Class $\mathrm{I}^{\mathrm{b}}$ \\
\hline & Yellow-orange & Golden yellow & Translucent & Yellow \\
\hline $2255 \mathrm{~A}$ & Semi-flint ${ }^{c}-Y^{d}$ & Sweet - T & Sweet - T & Semi-dent and Semi-flint - LY \\
\hline 2276A & Semi-dent - YE & Sweet - T & Sweet - T & Semi-flint and Dent - LY \\
\hline $2514 \mathrm{~A}$ & Semi-flint - YE & Sweet - T & Sweet - T & Semi-dent - LY \\
\hline $319 \mathrm{~A}$ & Dent - YE & Sweet - T & Sweet - T & Dent and Flint $-\mathrm{LY}$ \\
\hline 741B & Dent $-\mathrm{AC}$ & Sweet - T & Sweet - T & Semi-dent and Semi-flint - LY \\
\hline $2029 \mathrm{~A}$ & Semi-flint - YE & Sweet - T & Sweet - T & Semi-flint and Flint - YE \\
\hline $3000 \mathrm{~A}$ & Semi-flint and Dent - LY & Sweet - T & Sweet - T & Semi-flint and Flint - LY \\
\hline $3001 \mathrm{~A}$ & Flint - OY & Flint - YE & Flint -YE & Sweet -OY \\
\hline $2433 \mathrm{~F}$ & Dent - YE/OY & Dent - YE/OY & Dent - CO & Dent - YE/OY \\
\hline
\end{tabular}

${ }^{a}$ IDV: Variety identification as access to UFSC's Maize BAG; ${ }^{\mathrm{b}}$ Division into classes according to Boyer and Shannon (1984); ${ }^{\mathrm{c}} \mathrm{Grain}$ type; ${ }^{\mathrm{d}}$ Color: YE -Yellow; OY - Orange-Yellow or Orange; LY - Light Yellow; T - Translucent; CO - Colorful. Source: Authors. 
Figure 1. Result for grain type of allelic crossings. (a) and (b) F1 with sweet type grains. (c) F1 with semi-flint and dent type grains. (d) F1 with sweet type grains. (e) F1 with sweet type grains resulting from the reciprocal crossing between 3001A and BRS VIVI. (f) Grains of the variety 3001A and BR 400 (both with grains of the sweet type) and the grains of the flint type resulting from the crossing between the varieties.

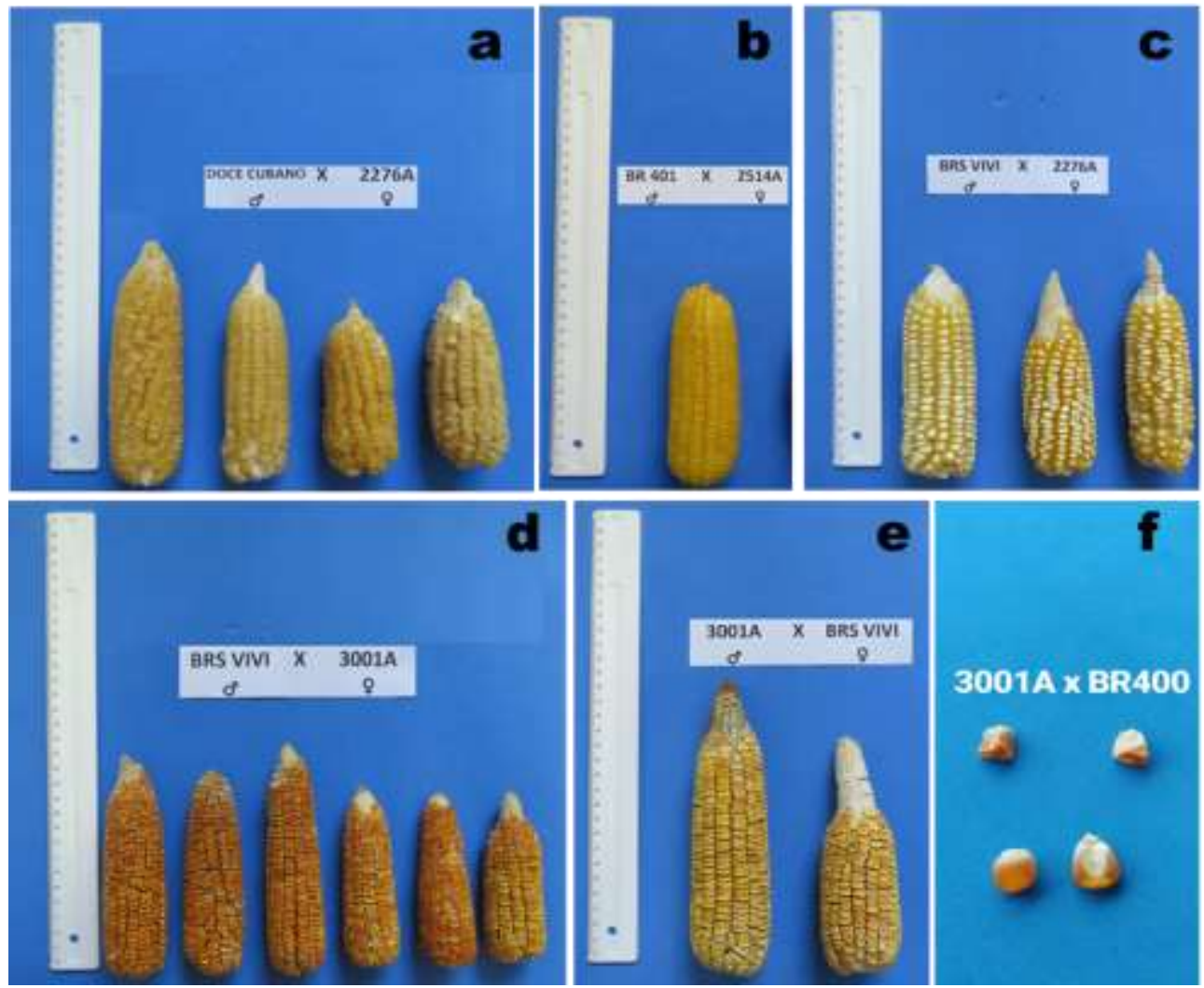

Source: Authors.

Regarding the phenotypic characterization as to grain phenotype, local varieties showed little diversity for qualitative characteristics of ear and grain, and a greater variation for quantitative data (Table 2). All varieties had wrinkled grains, white cob, and colorless pericarp. For grain color and endosperm, eight had translucent/colorless grains, two yellow and two orangeyellow, in addition to Embrapa's yellow-gold access. As for the arrangement of the rows, 11 varieties had ears with straight rows, one variety had spiral and straight rows, and one variety had spiral rows. As for the ear shape, seven varieties had conical-cylindrical ears, four cylindrical, one conical and one round.

As for the number of rows per ear (NR), 11 varieties had 14 rows, ranging from 12 to 18 , and two varieties had a 12 row mode. For the number of grains per row (NGR) and ear length (EL), the values ranged from 22.0 to $40.8 \mathrm{~cm}$ and 11.2 to 16.8 (17.1 cm Doce Cubano), respectively. Among the local varieties, the $2433 \mathrm{~F}$ variety, yellow, was the one with the highest values for NGR, EL, grain length (GL) and grain width (GW), and the lowest value for grain thickness (GT), with averages of $40.8,16.8 \mathrm{~cm}, 16.4 \mathrm{~mm}, 9.3 \mathrm{~mm}$ and $2.8 \mathrm{~mm}$, respectively. The 741B variety had the lowest values, with averages of 22.0 , $11.2 \mathrm{~cm}, 8.8 \mathrm{~mm}$ for NGR, EL and GL, in that order. 
Research, Society and Development, v. 10, n. 4, e46510414310, 2021

(CC BY 4.0) | ISSN 2525-3409 | DOI: http://dx.doi.org/10.33448/rsd-v10i4.14310

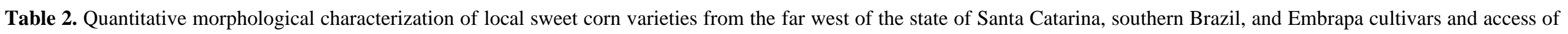
Embrapa's Maize BAG.

\begin{tabular}{|c|c|c|c|c|c|c|c|}
\hline $\begin{array}{l}\text { IDV }^{\mathrm{a}} / \\
\text { Variety name }^{\mathrm{b}}\end{array}$ & $\begin{array}{l}\text { Grain } \\
\text { color }^{\mathrm{c}}\end{array}$ & $\begin{array}{l}\mathrm{N}^{\mathrm{o}} \text { grains per row } \\
(\mathrm{cm})^{\mathrm{d}}\end{array}$ & $\begin{array}{l}\text { Ear length } \\
(\mathrm{cm})^{\mathrm{d}}\end{array}$ & $\begin{array}{l}\text { Ear diameter } \\
(\mathrm{cm})^{\mathrm{d}}\end{array}$ & $\begin{array}{l}\text { Grain length } \\
(\mathrm{mm})^{\mathrm{d}}\end{array}$ & $\begin{array}{l}\text { Grain width } \\
(\mathrm{mm})^{\mathrm{d}}\end{array}$ & $\begin{array}{l}\text { Grain thickness } \\
(\mathrm{mm})^{\mathrm{d}}\end{array}$ \\
\hline 2255A/Doce Branco & $\mathrm{T}$ & $36.6(27.2-46.0)^{\mathrm{e}}$ & $16.4(1.2-19.5)^{\mathrm{e}}$ & $4.3(3.7-4.8)^{\mathrm{e}}$ & $9.4(9.0-9.7)^{\mathrm{e}}$ & $7.2(7.0-7.5)^{\mathrm{e}}$ & $3.7(3.5-4.0)^{\mathrm{e}}$ \\
\hline 2276A/Branco & $\mathrm{T}$ & $31.4(23.8-39.0)$ & $13.4(10.8-16.0)$ & $4.8(4.4-5.1)$ & $11.5(11.3-11.8)$ & $7.5(7.2-7.8)$ & $4.2(4.0-4.5)$ \\
\hline 2433F/Doce & YE & $40.8(22.4-59.1)$ & $16.8(14.4-19.1)$ & $4.3(3.7-4.9)$ & $16.4(16.4-16.5)$ & $9.3(9.2-9.3)$ & $2.8(2.7-2.9)$ \\
\hline 2514A/Doce Branco & $\mathrm{T}$ & $23.8(12.3-35.3)$ & $12.6(9.6-15.6)$ & $4.6(3.4-5.8)$ & $10.6(10.1-11.1)$ & $7.6(7.3-7.9)$ & $3.7(3.4-7.0)$ \\
\hline 319A/Comum & $\mathrm{T}$ & $32.2(23.1-41.3)$ & $12.9(10.7-15.1)$ & $3.9(3.6-4.3)$ & $9.1(8.9-9.3)$ & $6.8(6.6-7.1)$ & $3.4(3.2-3.6)$ \\
\hline 741B/Branco & $\mathrm{T}$ & $22.0(10.2-33.8)$ & $11.2(5.5-16.8)$ & $4.0(3.3-4.6)$ & $8.8(8.1-9.5)$ & $7.5(6.9-8.0)$ & $3.8(3.5-4.1)$ \\
\hline 2029A/Murcho & $\mathrm{T}$ & $25.0(22.7-27.3)$ & $14.0(12.7-15.3)$ & $3.9(2.8-5.1)$ & $9.2(8.7-9.6)$ & $7.0(6.8-7.2)$ & $3.4(3.1-3.6)$ \\
\hline 3000A/Milho Verde & $\mathrm{T}$ & $30.5(28.7-32.3)$ & $12.7(9.8-15.5)$ & $4.0(3.7-4.3)$ & $9.2(8.9-9.5)$ & $6.5(6.3-6.7)$ & $3.1(2.9-3.3)$ \\
\hline 3001A/ Amarelo Doce & OY & $28.0(20.8-35.2)$ & $12.5(10.4-14.6)$ & $3.7(3.4-4.0)$ & $9.0(8.8-9.2)$ & $6.6(6.5-6.8)$ & $3.1(2.9-3.4)$ \\
\hline BR 400/Super Doce & OY & $29.2(24.4-34.0)$ & $15.2(14.0-16.5)$ & $4.0(3.6-4.4)$ & $8.4(8.0-8.8)$ & $7.1(6.8-7.3)$ & $2.7(2.5-2.9)$ \\
\hline BR 401/ Doce de Ouro & GY & $29.0(18.2-39.8)$ & $16.7(13.8-19.5)$ & $4.2(3.6-4.9)$ & $8.8(8.3-9.3)$ & $7.5(7.2-7.9)$ & $3.6(2.3-4.0)$ \\
\hline BRS Vivi & YE & $36.6(34.3-38.9)$ & $15.8(15.3-16.3)$ & $4.8(4.6-5.0)$ & $8.5(8.0-9.0)$ & $7.6(7.1-8.1)$ & $4.2(3.7-4.7)$ \\
\hline Doce Cubano & $\mathrm{T}$ & $34.6(31.4-37.8)$ & $17.1(16.7-17.5)$ & $4.7(4.5-4.9)$ & $9.6(9.1-10.1)$ & $7.6(7.1-8.1)$ & $3.9(3.5-4.2)$ \\
\hline
\end{tabular}

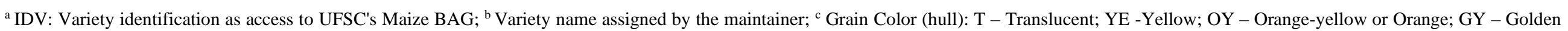
yellow; ${ }^{\mathrm{d}}$ Average of quantitative variables for each variety; ${ }^{\mathrm{e}}$ Confidence interval at $5 \%$ probability by Student's t-distribution. Source: Authors. 
For the ear diameter (ED), the varieties 2276A and 2514A presented larger diameters, being 4.8 and $4.6 \mathrm{~cm}$, respectively. The variables GL, GW and GT were the characteristics that showed the greatest variation between varieties, but with the least variation within the variety. The yellow grain varieties (local variety $2433 \mathrm{~F}$ and the cultivar BRS Vivi) showed larger ear sizes (EL and ED) and NGR. The varieties of translucent grains showed greater variations between varieties, with averages close to the varieties of yellow-orange color, for all variables, except for GW and NR. The cultivar BR 401 (yellowgold grains) presented values close to the translucent grain materials (Table 2).

The cluster analysis divided the set of varieties into four groups and one isolated variety (Figure 2). Group I consisted of the varieties 2514A, 741B, 319A and 2029A, all with translucent and similar grains for NGR, EL, and ED. Group II consisted of similar materials for GT, GW, NR and NGR, grouping the variety 3000A (translucent grains), with the variety 3001A and the cultivar BR400 (both with yellow-orange grains). Group III consisted of the cultivar BR 401 and the Doce Cubano variety of translucent grains, and the cultivar BRS Vivi, of yellow grains; similar for GW and EL. Group IV was formed by varieties 2276A and 2255A, with translucent grains and larger sizes for quantitative characters of ear and grain. Group V was formed only by the local variety $2433 \mathrm{~F}$, which differs from the other local varieties with yellow grains and greater ear and grain lengths.

Figure 2. Distance between local sweet corn varieties from the far west of the state of Santa Catarina, southern Brazil, and four accesses from Embrapa's Maize BAG. Gower's cofenetic correlation coefficient $(r=0.77)$, UPGMA clustering method.

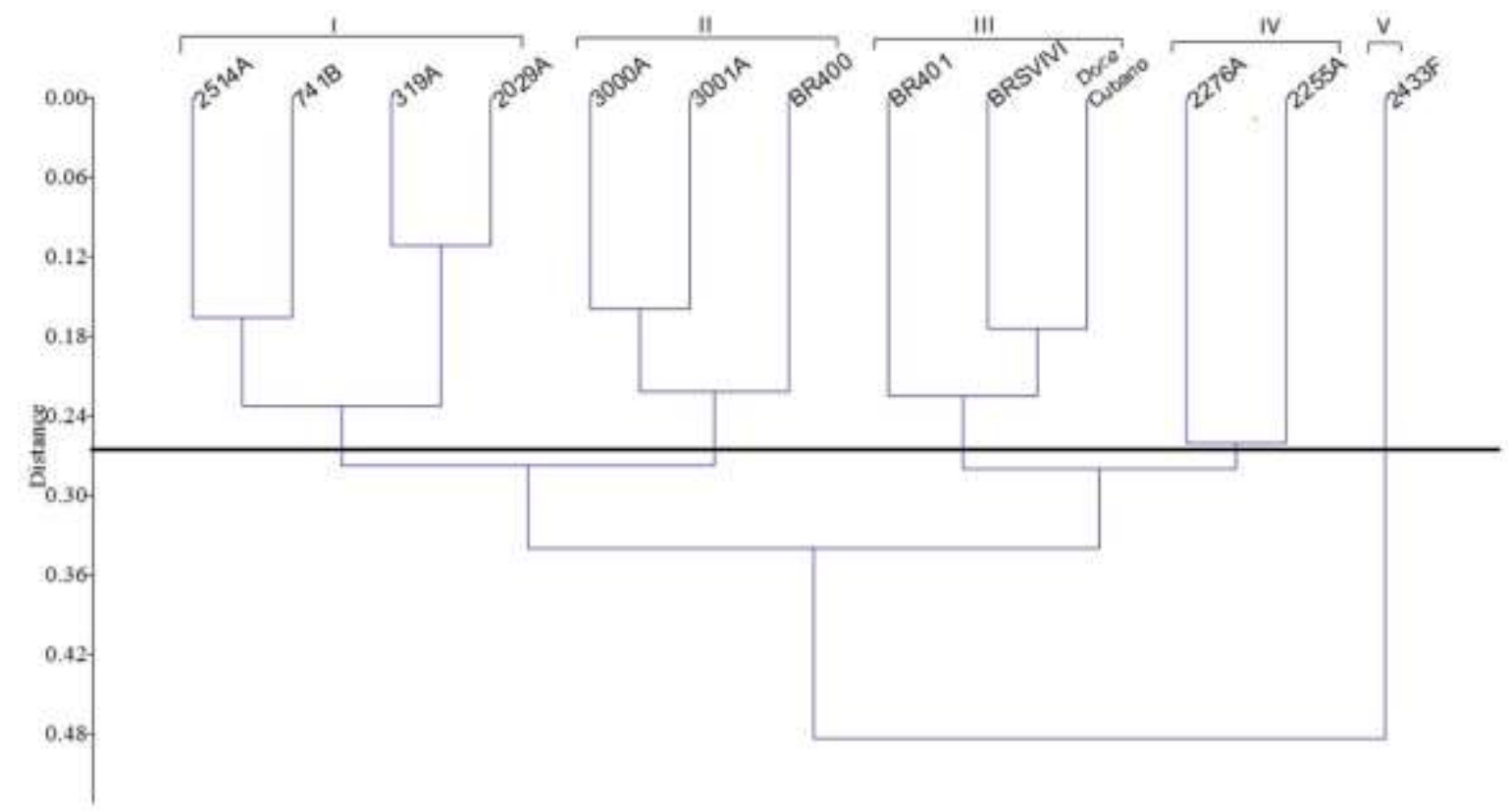

Source: Authors.

According to the PCA (Figure 3), the main components 1 and 2 explained 34.9 and 23.4\%, respectively, of the variation between the materials. Each component is representing a vector and it is considered that the larger the size, the greater the importance to explain the variability between the samples. Thus, according to the correlation coefficients between the variables and the first two PCA ranking components, the GT and NGR variables correspond to the variables with the highest weight in the first component. Within component 2, GW and GL are the variables with the greatest weight. 
Figure 3. Representation of the first two principal components (PC1 and PC2) explaining $58.3 \%$ of the total variation, extracted from the analysis of nine variables of nine local sweet corn varieties and four accessions of Embrapa's Maize BAG. Colored circles represent the same groups of dendrograms. Variables: (GC) grain color; (ES) ear shape; (RA) rows arrangement; (NGR) number of grains per row; (EL) ear length; (ED) ear diameter; (GL) grain length; (GW) grain width; (GT) grain thickness.

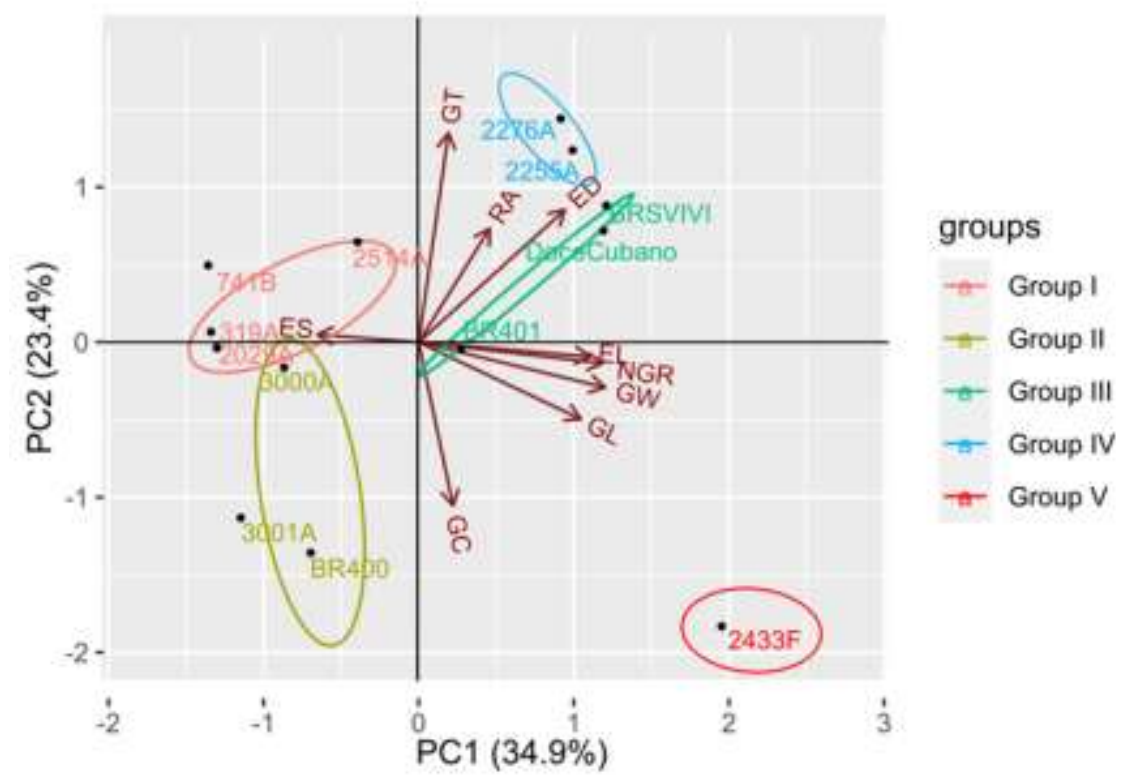

Source: Authors.

The characterization data and the clusters formed in the dendrogram (Figure 2) corroborate partially with the identification of the recessive alleles for sweet phenotype in the varieties of the FWSC. Group I (2514A, 741B, 319A, and 2029A), Group IV (varieties 2276A and 2255A) and variety 3000A of Group II, which have translucent and wrinkled grains when dry, carry the sugaryl gene. In general, varieties carrying this mutant allele showed larger ear size, weight and grain volume, when compared to variety 3001A, which carries the shrunken2 gene. According to Goldman and Tracy (1994), sweet corn containing the shrunken2 mutant has a smaller endosperm than sugaryl mutant, due to the effects of this mutant on starch synthesis, resulting in smaller and lighter grains. Oliveira Jr., Pereira and Bressan-Smith (2006) characterized and evaluated agronomically hybrids and lines of sweet corn and identified that the materials with the presence of the mutant allele sul presented ears and cobs of larger diameter, characteristic of sugaryl sweet corn.

It is possible to verify divergences regarding the morphological characteristics between the varieties that present the same mutant genes for the sweet phenotype. The varieties 2276A and 2255A (Group IV) differ for the ear size of the varieties 2514A, 741B, 319A and 2029A (Group I), of the same sulsul genotype. Still on the varieties of genotype sulsul, despite the great similarity for NGR, ED, and GW (Table 2), among the varieties of Group I, these show dissimilarity for the shape of ears, varying in conical, cylindrical, round and cylindrical-conical. However, the greatest dissimilarity among the local varieties carrying the sugaryl gene occurred with the 3000A variety, which was grouped with yellow-orange materials, 
Research, Society and Development, v. 10, n. 4, e46510414310, 2021

(CC BY 4.0) | ISSN 2525-3409 | DOI: http://dx.doi.org/10.33448/rsd-v10i4.14310

carrying two different genotypes for the sweet phenotype, and the variety 3001A (shrunken2 gene) and cultivar BR 400 (brittle2), with average values of ear length and length, width and thickness of grains very similar.

It is important to highlight that both the local varieties of translucent grains and the sulsul genotype (2514A, 741B, 319A, 2029A, 2276A, 3000A and 2255A), as well as the yellow-orange grape variety of the genotype $s h 2 s h 2$ (3001A), were not grouped with the accessions of corresponding sweet genotypes BR401 (sulsul), Doce Cubano (sulsul) and BRS Vivi $(\operatorname{sh} 2 \operatorname{sh} 2)$.

The non-grouping of local varieties with accessions of the same genotype for the sweet phenotype suggests that the diversity of sweet corn in the FWSC differs from that existing in the active genebank of Brazilian corn and that even though they possibly are descendants, they differ from one another depending on how long they have been cultivated by the farmers. The greatest example of dissimilarity between materials of the same genotype concerns the local variety 3001A with the hybrid BRS Vivi, both carriers of the shrunken2 mutant, responsible for the super sweet phenotype. These materials differ with respect to ear characteristics, grain color, and grain characteristics, despite the genotype for the super sweet phenotype (Tables 1 and 2; Figure 1).

The FWSC sweet corn varieties, as well as the two different identified mutants, sugaryl and shrunken2, represent an important diversity to be conserved and used in breeding programs, considering that Embrapa's Maize BAG, which houses the country's main germplasm collection, has only 20 accesses (Teixeira et al., 2019). It is worth mentioning that most of these accessions carry the sul mutant allele (Teixeira et al., 2019) and some materials, such as BR400 and BR401, have low genetic diversity (Almeida, Amorin, Barbosa Neto, Cardoso Filho \& Sereno, 2011). On the other hand, the shrunken2 mutant, not identified in Embrapa's collection (Teixeira et al., 2019), was identified as responsible for the super sweet phenotype in one local variety of this research (3001A), showing your importance as a source of genes to expand the genetic basis of sweet corn in Brazil.

Regarding the origin of the local sweet corn varieties in FWSC, these were obtained by farmers' families with neighbors, public institutions, local organizations, and local actions to enrich diversity, at an average of 11 years (ranging from 1 to 50 years), according to maintainers (Souza et al., 2020). About the origin accessions of sweet corn from Maize BAG of Embrapa, of the five accessions from collections, carried out in Brazil, only two were collected in the southern region of the country, in the state of Paraná in 1978 (Teixeira et al., 2019). The geographic proximity between the local sweet corn varieties of FWSC and the accessions from Maize BAG of Embrapa collected in the Parana state could suggest that the varieties of this corn type of the Santa Catarina are derived or descended from such accesses. However, when conserved by farmers over many years, the varieties are subject to constant diversification process, both by the selection pression of the agroecosystem and farmers (Ogliari et al., 2013), which leads to the differentiation of varieties, as evidenced by Silva et al. (2020) in studies with local popcorn varieties from the FWSC region. The same may be happening for sweet corn varieties in this region, corroborating with the genetic divergence of the varieties among themselves and with the accesses of Embrapa's Maize BAG.

As a consequence of the adaptive and evolutionary processes by which they are dynamically exposed, the varieties conserved on-farm do not present the same allele frequencies as the varieties collected and kept in the gene banks (Zeven, 1998). For the same reason, the local sweet corn varieties conserved in situ on-farm in the microcenter of diversity of the genus Zea in FWSC constitute to an important increase in sweet corn germplasm in Brazil, serving as sources of genes and gene combinations for the development of sweet corn breeding programs.

From the quantitative data, it was possible to identify enough genetic divergence for the formation of different groups by cluster analysis, and a potential variability within the varieties. However, it is necessary to design a differentiated selection 
Research, Society and Development, v. 10, n. 4, e46510414310, 2021

(CC BY 4.0) | ISSN 2525-3409 | DOI: http://dx.doi.org/10.33448/rsd-v10i4.14310

model, which meets the demands of FWSC farmers, and which manages to explore the genetic variability between and within the varieties, while allowing the development of varieties with wide adaptation.

The varieties 2029A, 741B, 2514A, 2276A, 319A, 3000A and 2255A, which have the same sugaryl mutant and showed potential for breeding, can be combined to form composite populations or intervarietal hybrids. The formation of compounds, from the varieties with the same mutant allele, contributes to conservation in situ on farm as it rescues the lost variability of populations that may present a high degree of inbreeding. The variety $3001 \mathrm{~A}$ (genotype $s h 2 s h 2$ ) stand out as material of greater genetic divergence, with potential for breeding, in addition to being extremely important for conservation, given the presence of the shrunken 2 mutant. This variety, of yellow-orange grain, presented the smallest sizes for ear and grain characters, that can be improved from selection.

Despite the importance of germplasm conserved in the FWSC, both for the conservation of diversity and for the sovereignty and food security of the families, local varieties of sweet corn and the other corn types of the diversity microcenter in FWSC are at constant risk of genetic erosion (Ogliari, 2018; Reichert Jr. et al., 2020; Souza et al., 2020). In this scenario, collecting and storing the diversity of Zea mays L. of this region in community and institutional banks of local seeds, added to the characterization and development of participatory improvement works, are tools that can strengthen the use and conservation of this local phytogenetic resource, both in situ on farm and ex situ.

Such strategies should be directed, mainly to the rare varieties, as is the case of the local variety $3001 \mathrm{~A}$, the only one that keeps the shrunken 2 mutant, and the variety $2433 \mathrm{~F}$, which has a sweet character, but that it was not possible to confirm in the present study which allele is responsible for the sweet phenotype.

The local variety $2433 \mathrm{~F}$, with an unidentified mutant genotype, presents wrinkled grains when dry, characteristics that differentiate sweet corn from other types of corn. In addition, it was superior to the other local varieties for characteristics of agronomic importance in the culture of sweet corn, such as number of grains per row, ear and grain length and grain width.

Owing to that fourteen mutants have been described in the literature for use in the sweet corn crop, that only eight of these have already been used commercially (Boyer \& Shannon, 1984; Tracy, 2001), and that three of these eight have been tested in the present study, at least, five new allele tests of the $2433 \mathrm{~F}$ variety with materials bearing different alleles for the sweet character should be performed. However, the other five known commercial mutant genes - brittle 1, amylose extenserl (ael), dull1 (dul), sugary enhancerl and waxyl (wxl) - are not found commercially in Brazil, neither in the collections maintained of Embrapa's Maize BAG, which would reinforce the rarity of the $2433 \mathrm{~F}$ variety concerning the mutant gene.

Regarding the need to test the $2433 \mathrm{~F}$ variety at crossings with other materials, the chances of being a new mutant allele are high, based on the following factors: (i) it is a local variety from a region of high diversity, recently indicated as a microcenter of diversity of the genus Zea (Costa et al., 2016; Silva et al., 2015), and which has been subjected to constant adaptive and evolutionary processes (Silva et al., 2017); (ii) it has typical morphological characteristics (ear size, length, width and grain thickness) of a local material, differing from Embrapa accessions and improved cultivars; and (iii) in the cluster analysis, the $2433 \mathrm{~F}$ variety was not grouped with any local variety, which indicates its particularity in relation to the other varieties, although it is derived from the same region.

Such factors highlight the importance of continuing genetic studies on the sweet phenotype of the 2433F variety, as well as characterizing attributes of interest in the culture of sweet corn, with a view to the chemical analysis of grains and to phenological and agronomic studies.

The results of the characterization of diversity, identification of distinct alleles for the sweet phenotype and detection of the selectable genetic variability of the local sweet corn varieties of the FWSC corresponded to a fundamental stage in the research of these materials. Based on the results obtained in the present study, integrated in situ on farm and ex situ 
Research, Society and Development, v. 10, n. 4, e46510414310, 2021

(CC BY 4.0) | ISSN 2525-3409 | DOI: http://dx.doi.org/10.33448/rsd-v10i4.14310

conservation strategies and the development of participatory breeding programs can contribute to the expansion of the genetic variability of this type of corn, in addition to encouraging conservation for the use of this local germplasm.

\section{Conclusion}

The allelic tests identified the presence of the sugaryl e shrunken 2 alleles as responsible for the sweet and super sweet phenotype of the local corn varieties of the FWSC. The morphological characterization and the cluster analysis divided the materials into four groups and one isolated variety whose gene encoding the sweet phenotype can be a rare gene or still unknown. The sweet and super sweet corn conserved in situ on farm in the microcenter of diversity of the genus Zea in the FWSC presents variability between and within, subject to selection in genetic improvement programs with a participatory focus.

\section{Acknowledgments}

To farmers and local FWSC organizations. To from Maize BAG of Embrapa. To the financial support agencies: National Council for Scientific and Technological Development, Co-ordination for the Improvement of Higher Education Personnel, Foundation for the Support of Research and Innovation of the State of Santa Catarina.

\section{References}

Almeida, C., Amorin, E. P., Barbosa Neto, J. F., Cardoso Filho, J. A. \& Sereno, M. J. C. M. (2011). Genetic variability in populations of sweet corn, common corn and teosinte. Crop Breeding and Applied Biotechnology, 11 (1), 64-69. doi.org/10.1590/S1984-70332011000100009.

Almekinders, C. J. M. \& Elings, A. (2001). Collaboration of farmers and breeders: participatory crop improvement in perspective. Euphytica, 122 (3), 425438.

Boyer, C. D. \& Shannon, J. C. (1984). The use of endosperm genes for sweet corn improvement. Plant Breeding Review, 1, 139-161.

Cardoso, E. T., Sereno, M. J. C, M. \& Barbosa, Neto J. F. B. (2002). Heritability estimates for quality and ear traits in sweet corn. Crop Breeding and Applied Biotechnolgy, 2 (4). doi.org/10.12702/1984-7033.v02n04a01.

Chambers, J. M. (2008). Software for data analysis: programming with R. Springer.

Coe, J. R. E. H. (1985). Phenotypes in corn: control of pathways by alleles, time and place. In Freeling, M. (ed). Plant genetics. 35, 509-521.

Coradin, L. (2006). Parentes silvestres das espécies de plantas cultivadas. MMA-SBF.

Costa, F. M., Silva, N. C. A. \& Ogliari, J. B. (2016). Maize diversity in southern Brazil: indication of a microcenter of Zea mays L. Genetic Resources and Crop Evolution, 64 (4), 681-700. doi.org/10.1007/s10722-016-0391-2.

Denney, J. O. (1992). Xenia includes metaxenia. HortScience, 27 (7), 722-728.

Goldman, I. L. \& Tracy, W. F. (1994). Kernel protein concentration in sugary-1 and shrunken-2 sweet corn. HortScience, 29 (3), $209-210$.

Hammer. Ø., Harper, D. A. T. \& Ryan, P. D. (2001). PAST: paleontological statistics software package for education and data analysis. Palaeontol Electron, 4 (1), 1-9.

IBPGR, C. (1991). Descriptors for maize. International Board for Plant Genetic Resources, Rome and International Maize and Wheat Improvement Center, Mexico City, Rome.

Jha, S. K., Singh, N. K. \& Agrawal, P. K. (2016). Complementation of sweet corn mutants: a method for grouping sweet corn genotypes. Journal of Genetics, 95 (1), 183-187. doi.org/10.1007/s12041-015-0608-8.

Kiesselbach, T. A. (1926). The immediate effect of gametic relationship and of parental type upon the kernel weight of corn. Research Bulletin: Bulletin of the Agricultural Experiment Station of Nebraska, 33, 1-69.

Machado, A. T. (2014). Construção histórica do melhoramento genético de plantas: do convencional ao participativo. Revista Brasileira de Agroecologia, 9 (1), 35-50.

MAPA (1997). Descritores mínimos de milho (Zea mays L.): sistema de proteção de cultivares. Diário Oficial da União, Brasília. 
Research, Society and Development, v. 10, n. 4, e46510414310, 2021

(CC BY 4.0) | ISSN 2525-3409 | DOI: http://dx.doi.org/10.33448/rsd-v10i4.14310

Mingoti, A. S. (2005). Análise de dados através de métodos de estatística multivariada: uma abordagem aplicada.

Ogliari, J. B. \& Alves, A. C. (2007). Manejo e uso de variedades de milho como estratégia de conservação em Anchieta. In: Boef, W. S., Thijssen, M. H., Ogliari, J. B. \& Sthapit, B. (Eds.), Biodiversidade e Agricultores: fortalecendo o manejo comunitário. L\&PM, $226-234$.

Ogliari, J. B. (2018). Presença do milho geneticamente modificado em um microcentro de diversidade, no Sul do Brasil. In: Delgado FDC (Ed.), Cuadernos de la Biored Iberoamérica CYTED, Cuaderno 6, Merida: Universidad Politécnica Territorial de Merida, 6, 31 -45.

Ogliari, J. B., Kist, V. \& Canci, A. (2013). The participatory genetic enhancement of a local maize variety in Brazil. In: Boef, W. S., Subedi, A., Peroni, N., Thijssen, M. \& O'Keeffe, E. (Eds.), Community biodiversity management, promoting resilience and the conservation of plant genetic resources. Routledge, Oxon, 265-271.

Oliveira Jr., L. F. G, Pereira, M. G. \& Bressan-Smith, R. (2006). Caracterização e avaliação agronômica de híbridos e linhagens de milho doce (su1). Horticultura Brasileira, 24 (3), 283-288. doi.org/10.1590/S0102-05362006000300003.

Reichert Jr., F. W., Souza, R., Pinto, T. T., Maghelly, O., Seledes, R. M., Avila, L. N. V. \& Ogliari, J. B. (2020). Diversity of crops conserved by family farmers in the extreme west of Santa Catarina, southern Brazil. In: Mossi, A. J., Petry, C. \& Reichert Jr., F. W. (Eds.), Agroecology insights, experiences and perspectives. 141-161.

Reifschneider, F. J. B., Gama, E. E. G. \& Reis, N. V. B. (1984). Milhos-doces: Superdoce (BR 400), Doce-de-ouro (BR 401) e Doce cristal (BR 402). Horticultura Brasileira 2 (2), 53-54.

Silva, N. C. A., Vidal, R. \& Ogliari, J. B. (2017). New popcorn races in a diversity microcenter of Zea mays L. in the far west of Santa Catarina, southern Brazil. Genetic Resources and Crop Evolution, 64 (6), 1191-1204. doi.org/10.1007/s10722-016-0429-5.

Silva, N. C. A., Vidal, R., Costa, F. M., Vaio, M. \& Ogliari, J. B. (2015). Presence of Zea luxurians (Durieu and Ascherson) Bird in southern Brazil: implications for the conservation of wild relatives of maize. PloS ONE, 10 (10), e0139034. doi.org/10.1371/journal.pone.0139034

Silva, N. C. A., Vidal, R., Ogliari, J. B., Costich, D. E. \& Chen, J. (2020). Relationships among American popcorn and their links with landraces conserved in a microcenter of diversity. Genetic Resources and Crop Evolution, 67 (7), 1733-1753. doi.org/10.1007/s10722-020-00935-2

Souza, R., Ogliari, J. B. \& Pinto. T. T. (2020). Analysis of on farm conservation of sweet corn in a diversity microcenter of Zea mays L. in southern. Maydica, 65 (9).

Strickberger, M. W. (1968). Genetics. Macmillan,

Teixeira, F. F., Guimarães, C., Pinto, M. D. O., Pereira Filho, I. A., Coelho, R., Araújo, G. D. R. \& Pontello, I. D. O. (2019). Catálogo de acessos do Banco Ativo de Germoplasma de Milho com grãos do tipo doce. Embrapa Milho e Sorgo-Documentos (INFOTECA-E).

Teixeira, F. F., Paes, M. C. D., Gama, E. G., Pereira Filho, I. A., Miranda, R. A., Guimarães, P. E. O., Parentoni, S. N., Cotta, L. V., Meirelles, W. F., Silva, A. R. \& Machado, J. R. A. (2014). BRS Vivi: single-cross super sweet corn hybrid. Crop Breeding and Applied Biotechnology, 14 (2), 124-127. doi.org/10.1590/1984-70332014v14n2c21.

Tracy, W. F. (2001). Sweet corn. In: Hallauer, A. R. (Ed), Specialty corn. CRC Press, B. Raton, 155-198.

Zeven, A. C. (1998). Landraces: a review of definitions and classifications. Euphytica, 104 (2), 127-139. 